\title{
МАТЕМАТИЧНЕ МОДЕЛЮВАННЯ ЯК СУЧАСНИЙ ІНСТРУМЕНТ ПРОГНОЗУВАННЯ ЕФЕКТИВНОСТІ ПРОТИРОТАВІРУСНИХ ВАКЦИН
}

\section{С. О. Соловйов}

\author{
Національна медична академія післядипломної освіти імені П. Л. Шупика
}

\begin{abstract}
Методами молекулярно-біологічних досліджень оцінені особливості циркуляції генотипів ротавірусів на території України. На основі отриманих даних методами дистрибутивного і мультиплікативного синтезу, що були застосовані вперше в подібних розрахунках, оцінена прогнозна генотип-специфічна ефективність вакцини на основі штаму ротавірусів RIX4114 з генотипом G1P. Це дозволило отримати попередню оцінку ефективності до проведення клінічних випробувань. Встановлено, що її розрахункове значення досить високе $(80,4$ \%) за умови її масового використання серед населення.
\end{abstract}

Ключові слова: ротавіруси, протиротавірусна вакцина, генотипи, ефективність, аналітичний метод.

\section{МАТЕМАТИЧЕСКОЕ МОДЕЛИРОВАНИЕ КАК СОВРЕМЕННЫЙ ИНСТРУМЕНТ ПРОГНОЗИРОВАНИЯ ЭФФЕКТИВНОСТИ ПРОТИВОРОТАВИРУСНЫХ ВАКЦИН}

\begin{abstract}
С. А. Соловьев
Национальная медицинская академия последипломного образования имени П. Л. Шупика

Методами молекулярно-биологических исследований оценены особенности циркуляции генотипов ротавирусов на территории Украины. На основе полученных данных методами дистрибутивного и мультипликативного синтеза, примененными впервые в подобных расчетах, была оценена прогнозная генотип-специфическая эффективность вакцины на основе штамма ротавирусов RIX4114 с генотипом G1P. Это позволило получить предварительную оценку эффективности до проведения клинических испытаний. Установлено, что ее расчетное значение достаточно высоко (80,4 \%) при условии ее массового использования среди населения Украины.
\end{abstract}

Ключевые слова: ротавирусы, противоротавирусная вакцина, генотипы, эффективность, аналитические методы.

\section{MATHEMATICAL MODELING AS A MODERN TOOL OF PROJECTING THE EFFICACY OF ROTAVIRUS VACCINES}

\section{S. O. Solovyov}

\author{
National Medical Academy of Post-Graduate Education by P. L. Shupyk
}

\begin{abstract}
With the use of molecular biological studies there were estimated the peculiarities of the circulation of rotavirus genotypes on the territory of Ukraine. It was estimated predictive genotype-specific efficacy of the vaccine based on rotavirus strain RIX4114 with genotype G1P, based on the methods of distribution and multiplicative synthesis, which were used for the first time in such calculations. This allows obtaining a preliminary evaluation of its efficacy prior to clinical trials. It was established that the calculated value is sufficiently high $(80,4 \%)$ in conditions of its mass use among population of Ukraine.
\end{abstract}

Key words: rotaviruses, rotavirus vaccine, genotypes, efficacy, analytical methods

Вступ. Однією з найбільш значущих проблем охорони здоров'я в усіх країнах світу $є$ гострі кишкові інфекції (ГКІ). Спектр збудників, що викликають ГКІ, різноманітний і включає патогенні та умовно-патогенні бактерії, найпростіші, а також віруси. Серед них саме ротавірусній інфекції (PBI) належить провідна роль в структурі вірусних діарейних захворювань у новонароджених і дітей віком до 5 років. В Україні статистичний облік захворювання на PBI введено лише на початку 90-х років ХХ століття. Тоді їі показники в окремі роки коливались від 0,94 до 3,18 на 100 тисяч населення, і значна кількість випадків залишалася етіологічно не розшифрованою (близько 45 \%). Згодом серед загальної популяції населення та у

(C) С. О. Соловйов, 2011 
родопомічних закладах, спеціалізованих неонатологічних відділеннях були зареєстровані спалахи РВI в Одесі і Одеській області (2001-2002 pр.), у м. Києві (2005-2007 pp.) [3, 4].

Нова моновалентна протиротавірусна вакцина на основі атенуйованого штаму ротавірусу людини RIX41 14 з генотипом G1P[8], який є найбільш поширеним у світі [5]. Штам RIX4114 був одержаний 3 початкового штаму 89-12, ізольованого від дитини 3 ротавірусним гастроентеритом під час спалаху ротавірусної інфекції в Цинциннаті (США) в період 19881989 рр. Перші клінічні спостереження показали, що цей штам індукував високий рівень імунного захисту проти РВI протягом наступного сезону [6]. 3 метою атенуйування початковий штам 89-12 ротавірусу культивували впродовж 26 пасажів на первиннотрипсинізованій культурі клітин нирки африканської зеленої мавпи (AGMK) та впродовж 7 пасажів у перещеплювальній культурі клітин AGMK. Надалі 334 по 43 пасажі вірус культивували в перещеплювальній культурі клітин Vero, в лабораторії компанії GlaxoSmithKline Biologicals (Rixensart, Бельгія), де i було отримано остаточний вакцинний штам - кандидат RIX4114, який виявляв високу імуногенність, але втратив інфекційні властивості по відношенню до людини [7]. Вакцина індукує перехресну імунну відповідь не тільки проти аналогічних ротавірусних штамів, що циркулюють серед людей (тобто з генотипом G1P[8]), але також і проти вірусів 3 меншою гомологією рецепторних білків, чий G/Р-генотип відрізняється від вакцинного штаму [7].

Протиротавірусна вакцина на основі цього штаму сьогодні розглядається як найбільш ефективна, що здатна зменшити кількість важких випадків ротавірусних дегідратуючих діарей з летальними наслідками у дітей молодшого віку та загальну кількість випадків, що потребують госпіталізації. Ї̈ ефективність виявилась досить високою, що підтверджено клінічними дослідженнями серед дітей в Свропі та в Латинській Америці [8, 9]. Проте залишається непевність, наскільки ефективною ця вакцина буде в Україні, де вона зареєстрована та включена в календар профілактичних щеплень, затверджений Наказом МО3 України №765 від 09.09.10 р. (Розділ 4. Рекомендовані щеплення) [10]. Саме тому особливої актуальності набуває розробка математичних методів прогнозування ефективності і наслідків такої вакцинації, оскільки таке прогнозування буде досить інформативним ще до початку клінічних досліджень.

Мета роботи полягала у застосуванні методів математичного моделювання для прогнозування генотип-специфічної ефективності прогирогавірусної вакцини на основі штаму ротавірусу людини RIX4114, з урахуванням особливостей циркуляції ротавірусів різних генотипів серед дітей в Україні.

Матеріали та методи досліджень. Вірусологічними та молекулярно-біологічними дослідженнями було охоплено 600 дітей (клінічний матеріал) у віці до 5 років з ГКІ, з м. Києва (181 дитина), м. Львова (97 дітей), м. Умані (99 дітей), Одеської (70 дітей), Сумської (100 дітей), Харківської (100 дітей) областей. Індикацію ротавірусів в клінічному матеріалі здійснювали (IФА) 3 використанням тест-систем Ridascreen®ELISA (R-biopham, Німеччина) та методом полімеразної ланцюгової реакції (ЗТ-ПЛР) 3 використанням тест-системи АмпліСенс $®$ RotavirusEPh (ФГУН ЦНДІ епідеміології Росспоживнагляду, Росія) 3 детекцією продуктів ампліфікації методом електрофорезу в агарозному гелі. Генотипування ротавірусів в позитивних пробах (210 проб) проводили адаптованим методом [P]G генотипування ротавірусів групи А за А.Т. Подколзіним [11].

Прогнозування генотип-специфічної ефективності вакцини проводили за методом мультиплікативного синтезу [12], та за методом J. Rose, який вперше використав метод дистрибутивного синтезу для прогнозування ефективності ротавірусної вакцини [13].

Метод розрахунку ефективності вакцини на основі штаму RIX4114 грунтується на даних клінічних спостережень ефективності вакцини у дітей з 11 Латиноамериканських країн, де було показано різний ступінь їі ефективності проти важкого гастроентериту, спричиненого ротавірусами з генотипами G1P[8], G3P[8], G4P[8], G9P[8] та G2P[4], ізольованими від цих дітей [8]. Всі ізольовані штами були згруповані відповідно до різних ступенів гомології з вакцинним штамом G1P[8], а саме: збігались за G- та Р-генотипами; збігались тільки за одним, G- або Р-генотипом; не збігались за жодним з генотипів. Були визначені відповідні частки кожної групи в загальній циркуляції генотипів ( $w^{C}=\left\{w_{j} \mid j=\overline{1,3}\right\}$ ) як нормовані ваги критерію $\mathrm{C}_{j}$ За критерій $C=\left\{C_{j} \mid j=\overline{1,3}\right\}$ було прийнято ступінь гомології по відношенню до вакцинного штаму. Ефективність вакцини проти штамів певної групи гомології була отримана 3 даних клінічних спостережень [8], та позначена як V. - ненормована вага за критерієм С..

За методом дистрибутивного синтезу, або лінійною згорткою, сумарна ефективність вакцини розраховується за формулою. 


$$
w_{\text {дистрибутивна }}^{\text {сумарна }}=\sum_{j=1}^{N} w_{j}^{C} \cdot v_{j}, j=\overline{1, N}, N=3 \text {. }
$$

За методом мультиплікативного синтезу, або мультиплікативною згорткою, сумарна ефективність вакцини розраховується за формулою (2) для зваженої середньої геометричної:

$w_{\text {мультиилгікативна }}^{\text {сумарна }}=\prod_{j=1}^{N}\left(v_{j}\right)^{w_{j}^{c}}, j=\overline{1, N}, \mathrm{~N}=3$.

Результати та обговорення. Було досліджено циркуляцію G/Р-генотипів ротавірусів в двох регіонах України: місті Києві та Одеській області, які вирізняються серед інших регіонів великою щільністю та інтенсивною міграцією населення. За досліджуваний період у структурі ГКІ вірусної етіології в різних містах України ротавіруси становили: у Львові - 51 $\%$, в Одесі - $42 \%$, у Чернігові та Сумах - $15 \%$, в Харкові - 30 \%, у Києві - 20 \%. Підтверджено зимо- во-весняну сезонність ротавірусної інфекції, оскільки максимальне число випадків РВI було виявлено у дітей в січні та лютому. У віковій групі дітей до 3 років середня частота виявлення ротавірусів була найбільшою і становила $(70,1 \pm 4,0) \%$. В результаті генотипування відібраних 210 позитивних зразків у 176 випадках (83,8 \%) були виявлені Р-генотипи і в 182 випадках О-генотипи ротавірусів (86,6 \%). В 3,3 $\%$ зразків не було виявлено Р-генотип, в 4,3 \% - Огенотип, і в 5,7 \% випадків не виявлялися обидва генотипи. В досліджуваний період була виявлена циркуляція чотирьох основних генотипів РВ групи А: О1Р[8], О4Р[8], О3Р[8], О2Р[4]. Слід відзначити, що в Києві, Львові, Одесі та Харкові більшість випадків PBI (більше 70 \%) було викликано ротавірусом групи А з генотипом О1Р[8]. В Сумах домінував генотип О4Р[8]. В Одесі в окремих випадках були виявлені ротавіруси генотипу О9Р[8]. Загальна картина циркуляції ротавірусів різних генотипів представлена на рисунку 1.

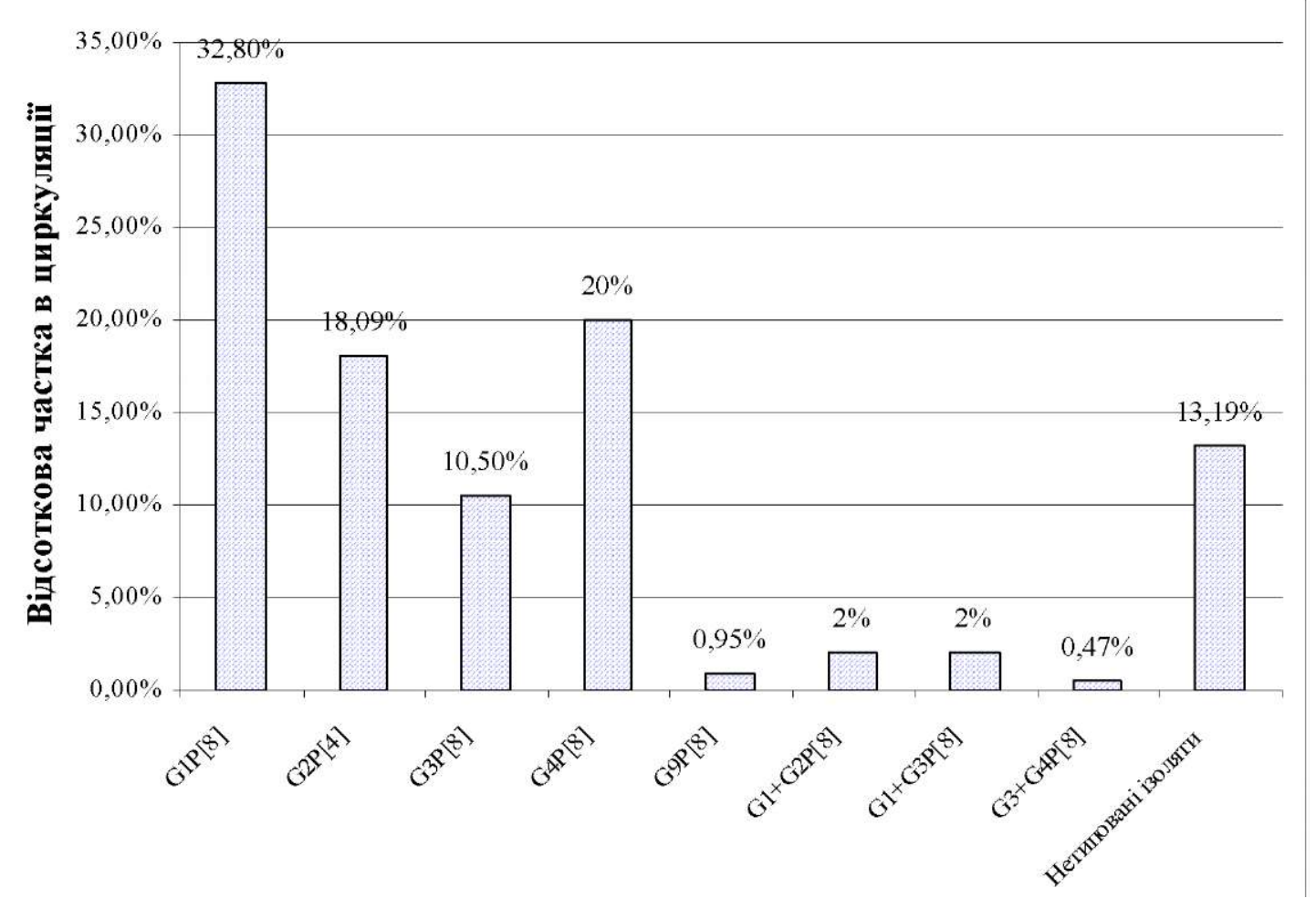

Генотипи ротавірусів

Puc. 1. Циркуляція різних G-, Р-генотипів ротавірусів групи А, виділених на території України в 2006-2009 роках від дітей з гострим гастроентеритом $(\mathrm{N}=210)$.

Результати молекулярно-генетичного дослідження циркуляції ротавірусів серед населення України були згруповані в кожному випадку за ступенем гомології до вакцинного штаму ротавірусів RIX4114 3 генотипом О1Р[8] та визначена частка кожної групи серед усіх позитивних знахідок (рис. 2). Було прийнято, що нетиповані ізоляти не мають гомології вакцинному штаму. 


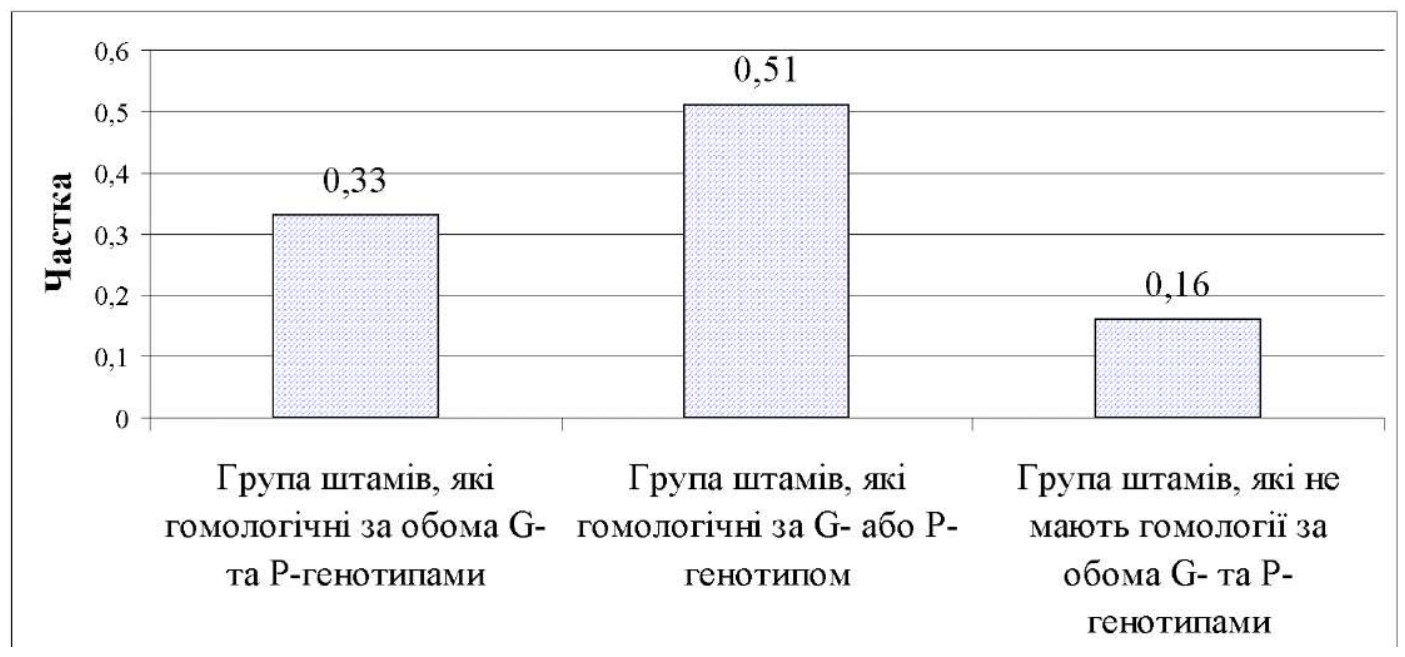

\section{Групи гомології}

Puc. 2. Частки груп циркулюючих штамів ротавірусів відповідно до гомології вакцинному штаму MХ4114 3 генотипом О1P[8].

Методами дистрибутивного та мультиплікативного синтезу було розраховано прогнозну генотип-специфічну ефективність вакцини на основі штаму MX4114 з генотипом O1[8]. Для України була встановлена на рівні - 0,812 проти важкого ротавірусного гастроентериту > 11 балів за шкалою Уе8Ікагі методом дистрибутивного синтезу та на рівні 0,795 методом мультиплікативного синтезу (Табл. 1). Середнє значення теоретично розрахованої генотип-специфічної ефективності вакцини складає 0,804 , тобто у випадку іiі застосування в Україні кількість важких випадків ротавірусної інфекції серед дітей раннього віку зменшиться на 80,4 \%.

За даними літератури відомо, що наведена методика прогнозування специфічної ефективності вакцини був перевірена 3 використанням даних фази II іï

Таблиця 1. Очікувана ефективність протиротавірусної вакцини на території України

\begin{tabular}{|c|c|c|c|c|}
\hline \multirow[b]{2}{*}{$\begin{array}{c}\text { Групи штамів ротавірусів, за } \\
\text { ступенем гомології до вакцинного } \\
\text { штаму G1P[8] }\end{array}$} & \multirow[b]{2}{*}{$\begin{array}{c}\text { Поширення } \\
\text { генотипів на } \\
\text { території } \\
\text { України, } w_{j}\end{array}$} & \multirow{2}{*}{$\begin{array}{c}\text { Генотип-специфічна } \\
\text { ефективність вакцини } \\
\text { проти важкого } \\
\text { ротавірусного } \\
\text { гастроентериту } \\
\text { з важкістю за шкалою } \\
\text { Vesikari } \geq 11 \text { балів [8], } v_{j}\end{array}$} & \multicolumn{2}{|c|}{ Результат } \\
\hline & & & $\begin{array}{l}\text { дистрибу- } \\
\text { тивний } \\
\text { синтез } \\
\boldsymbol{w}_{j}^{C} \cdot \boldsymbol{v}_{j}\end{array}$ & $\begin{array}{c}\text { мульти- } \\
\text { плікативний } \\
\text { синтез } \\
\left(v_{j}\right)^{w_{j}^{C}}\end{array}$ \\
\hline Гомологічні за G- та Р-генотипами & 0,33 & 0,908 & 0,3 & 0,969 \\
\hline Гомологічні за G- або Р-генотипом & 0,51 & 0,869 & 0,44 & 0,931 \\
\hline $\begin{array}{c}\text { Не мають гомології за G- та P- } \\
\text { генотипами }\end{array}$ & 0,16 & 0,454 & 0,072 & 0,881 \\
\hline \multicolumn{3}{|l|}{ Сумарна ефективність } & $\Sigma=0,812$ & $\Pi=0,795$ \\
\hline
\end{tabular}

клінічних досліджень в Фінляндії [9]. Використовуючи дані щодо поширення генотипів ротавірусів серед дітей в групі дослідження, було оцінено очікувану ефективність вакцини на рівні 0,859 (85,9\%) методом дистрибутивного синтезу, та 0,847 (84,7\%) методом мультиплікативного синтезу та ї̈ середнє значення - 0,853. В той же час за даними клінічних спостережень фактична ефективність вакцини в цій групі склала 0,86 (86 \%) (95\% довірчий інтервал: 0,63 - 0,96), що підтверджує адекватність використовуваної методики.
Висновки. Показано, що ротавіруси групи А $є$ основними етіологічними агентами вірусних гастроентеритів у дітей у віці до п'яти років в Україні. Вперше проведено молекулярно-генетичні дослідження та аналіз генотипів ротавірусів групи А, циркулюючих в Україні. В результаті генотипування ізолятів визначено домінуючі генотипи ротавірусів групи А: 01P[8], О4Р[8], О3Р[8], О2Р[8]. Вивчені особливості територіального поширення штамів ротавірусів, що має першочергове значення при ви- 
рішенні питання впровадження специфічної профілактики ротавірусної інфекції. 3 використанням принципово нових аналітичних методів розраховано високу прогнозну генотип-специфічну ефективність вакцини на основі штаму RIX4114 з генотипом 01 [8]

\section{Лiтература}

1. Rotavirus and severe childhood diarrhea / U. D. Parashar, C. J. Gibson, J. S. Bresse, R. I. Glass // Emerg. Infect. Dis. 2006. - \# 12. - P. 304-306.

2. Burden of rotavirus desease in European union countries / M. Soriano-Gabarro, J.Mrucowicz, T. Vesicari [et al.] // Pediatric Ivfect. Dis. -2006. - Vol. 25. - P. 7-11.

3. Дзюблик І.В. Виявлення ротавірусної інфекції у дітей в зимово-весняний період 2006-2007рp. / [І .В. Дзюблик, О.В. Обертинська, І.Г. Костенко та ін.] // Раціональна фармакотерапія. - 2008. - № 3/2. - С. 77-80.

4. Дзюблик І.В. Ротавірусна інфекція у дітей України / [I. В. Дзюблик, О.В. Обертинська, І.Г Костенко та ін.] // Профілактична медицина. - 2009. - № 2. - С. 34-37.

5. Santos N, Hoshino Y. Global distribution of rotavirus serotypes/genotypes and its implication for the development and implementation of an effective rotavirus vaccine. / N. Santos, Y. Hoshino Rev. Med. Virol. - 2005. - Vol. 15 (1): P. 29-56.

6. Rotarix: development of a live attenuated monovalent human rotavirus vaccine. / D. I. Bernestein, R. L. Ward Pediatr. Ann. 2066. - 35. - P. 38-43 (2006).

7. Safety and immunogenicity of live, attenuated human rotavirus vaccine 89-12. / D. I. Bernstein, V E. Smith, J. R. Sherwood [et al.] Vaccine. - Vol. 16(4). - P. 381-387 (1998). для України. На основі результатів молекулярно-біологічних досліджень було показано, що за умови використання вакцини на території України, кількість важких випадків ротавірусної інфекції серед дітей раннього віку буде зменшена на 80,4\%.

8. Evaluation of safety, immunogenicity and efficacy of an attenuated rotavirus vaccine, RIX4414: A randomized, placebocontrolled trial in Latin American infants. / B. Salinas, I. Perez Schael, A. C. Linhares, [et al.] Pediatr Infect Dis J. - 2005. - Vol. 24(9). - P. 807-16.

9. Efficacy of RIX4414 live attenuated human rotavirus vaccine in Finnish infants. / T. Vesikari, A. Karvonen, L. Puustinen, [et al.] Pediatr. Infect. Dis. - 2004. Vol. 23(10). - P. 937-943.

10. Наказ МОЗ України № 765. "Про порядок проведення профілактичних щеплень в Україні та контроль якості й обігу медичних імунобіологічних препаратів".

11. Подколзин А. Т. Адаптированная к практическому применению методика $[\mathrm{P}] \mathrm{G}$ генотипирования ротавирусов группы А / А. Т. Подколзин, Е. Б. Фенске, Н. Ю. Абрамычева [и др.] // Молекулярная диагностика - 2007 : сб. тр. 6-ой Всерос. науч .-практ. конф. с международным участием. M., 2007. - T. 3. - C. 284-286.

12. Недашювська Н. І. Ощнювання реверсу рангів в метода аналзу ієрархій / Н. І. Недашківська // Системи дослідження та шформацшт технології. - 2005. - № 4. - С. 120-130.

13. Johnie Rose. Simulating the impacts ofmass vaccination with live attenuated human rotavirus vaccine in a developing country. Thesis/dissertation for the Doctor of Philosophy degree. Case Western Reserve University. January, 2010. 